\title{
PURE POLITICKING! RACIALISED BLAME GAMES AND MORAL PANIC IN THE CASE OF A SOUTH AFRICAN HIGH SCHOOL
}

\author{
MARTHINUS STANDER CONRADIE ${ }^{1}$ \\ ${ }^{1}$ University of the Free State, Department of English, PO Box 339, Bloemfontein 9300, South Africa. \\ ORCID: 0000-0003-2929-8616, Email: conradiems@ufs.ac.za
}

\begin{abstract}
This study combines two discourse analytic frameworks, and explores the utility of this combination for unpacking journalistic opinions written in response to a polarising and racialised event in South African education: the Overvaal High School incident. It uncovers strategic constructions of racism within politicised blame games, in the context of Overvaal, and discloses how blame-assertion and blame-denial became implicated in framings of moral panic. Methodologically, this study relies on the concept race trouble, as well as a practical model of argumentation. In conjunction, these two approaches supply insight into both the calculated construction of racism, as well as the incorporation of these constructions into arguments aimed at rationalising blame-assertion and blame-denial. The results are interpreted within theorisations of moral panic. The findings showcase how arguments are produced to blame an individual politician for escalating racial antagonism around Overvaal, instead of offering a deeply historicised and contextualised account of the incident. Consequently, the arguments that shaped the opinion pieces, and the framing of racism involved in these arguments, ultimately obfuscate inquiry into structural determinants of racial inequity. Implicitly, this framing of racism and its incorporation into argumentation and blame games, produce a form of moral panic, in which South Africans racialised as white are construed as embattled by self-serving (black) politicians. Such politicians are vilified, or rendered as folk devils, and the results indicate how this process evades penetrating analyses of racialisation and its intersection with unequal education.

KEYWORDS: racist, South Africa, blame-attribution, blame-denial, argumentation, news media
\end{abstract}




\section{INTRODUCTION}

This study complements discourse analyses on interconnections between blame-attribution, processes of racialisation and constructions of moral panic. The analysis centres on the warrants (conditional if- $X$-then- $Y$ argumentative structures) uncovered from journalistic opinion pieces on the Overvaal incident. This racialised furore in South African education provoked violent protests, police arrests, and high media attention. Several media reactions to the debacle foregrounded social actors and arrangements that could be held accountable for the damage incurred. However, despite the presence of structural determinants, most opinion pieces blamed an individual politician for amplifying racial aggression.

Blame-attribution involves the social construction of moral codes or behavioural standards, and the application of these standards for framing problems and searching for culprits. Blame typically accrues to those who contravene these agreed-upon (yet constructed) codes of conduct. However, allocating blame to such culprits in a simplistic fashion can obfuscate other, more complicated determinants of the problem. The opinion pieces analysed for this study reflect such simplifying patterns. On the one hand, the authors of accusatory arguments justified their attack upon an individual politician based on the democratically-enshrined duties of public officials, which this politician had contravened; however, on the other hand, the same arguments ultimately elided other decisive facets of racial inequity. These results remind that even blame games premised on the constitutionally-codified duties of public officials can became ideologically problematic.

By discerning the nuances of blame-relevant argumentation in the opinion pieces written in response to the Overvaal event, I aim to disclose how standards of culpability are construed, applied to social actors, and interpolated with racism. I hone my analysis to the underlying conditional premises, the if- $A$-then- $B$ argumentative structures, which underpin blame-attribution in the opinion pieces. To do this, I first deploy Toulmin's (2003) model of argumentation. Second, since the opinion pieces encompass strategic constructions of racism to justify its arguments, I combined Toulmin's (2003) framework with Cresswell, Whitehead and Durrheim's (2014) conceptualisation of race trouble.

Conjoining these frameworks can guide and deepen the question as to whether opinion pieces on Overvaal acknowledged or refuted structural racism. In what follows, I describe events around Overvaal, which inspired the online opinion pieces that represent the textual data on which my discourse analysis was conducted. Thereafter, I elucidate Toulmin's (2003) model, Hansson's (2018a) expansion of this framework, and Cresswell et al's (2014) race trouble as a means of analysing argumentation and race in the online opinion pieces under study. Finally, I report the findings of the discourse analysis and interpret the dominant patterns as a racialised instance of moral panic. The rest of this introduction briefly outlines Toulmin (2003), race trouble and the potential efficacy of these approaches for unravelling intersections between blame games, racialisation and moral panic.

First, Toulmin (2003) prioritises inquiry into warrants. As a heuristic device, war- 
rants signify discursive repertoires that play a linking role between argumentative claims and supporting evidence. Warrants specify the normative conditions under which the claims informing an argumentative position can be said to derive from the evidence adduced to uphold those claims. Since warrants are typically articulated implicitly, and since they often hinge on ideologically-productive assumptions, analysing their linking function between claims and evidence can help to untangle the strategies used to rationalise blame-relevant argumentation. Hansson (2018a) expands this work to gain traction on the functions warrants perform in blame games. These are conceptualised as "offensive and defensive symbolic performances", during which claims and evidence are offered to: 1 ) contrive behavioural standards for adjudicating the culpability of potential wrongdoers, and subsequently 2) to argue for or against the blameworthiness of these targets (Hansson2018b: 228).

Second, race trouble emanates from the conceptualisation of media discourses as socially constituted and constitutive. Cresswell et al. (2014) use race trouble to uncover the discursive repertoires and situated practices that frame and reframe racism, making it expedient for parochial interests. Applying race trouble entails tracking how different framings are formulated and made functional to particular interests such as blame-making and blame-avoidant argumentation. Moreover, relying on race trouble also sheds light on elements of racism that are occluded. Taking online opinion pieces written about Overvaal as a case study, I question whether and how these opinion pieces root arguments within systemic understandings of racism, or whether comparatively more micro-level issues are favoured. The findings suggest the recycling of an existing discursive practice, in which culturally white educational institutions are constructed as embattled.

In terms of moral panic, the findings denote an arrangement of practices that pin blame to an individual politician, until he symbolises corrupt, self-interested politicking. Since the politician in question raised accusations of racism against the governing body of Overvaal High School, he is held accountable for aggravating racial conflict. As such, the opinion pieces register a moral outrage at the prospect that politicians can abuse accusations of racism to sediment their own reputations as social justice advocates. In doing so, the opinion pieces circumvent other questions about racism in favour of treating it mainly as a politicised resource.

\section{THE CASE STUDY: OVERVAAL HIGH SCHOOL}

This study conducts a discourse analysis of blame in online opinion pieces written in respond to events surrounding the Overvaal incident in South Africa. The following contextual information is vital for an understanding of how blame is attributed or deflected in the opinion pieces under study.

Education in South Africa suffers from severe infrastructural shortages. Consequently, many young learners are compelled to cover demanding distances, at personal cost, to attain education when schools closer to home are full. High School Overvaal is situated in the densely populated Gauteng province, and its governing body was called upon to alleviating local shortages. In December 2017, the Gauteng Department 
of Education required the school to enrol fifty-five more learners for 2018, who would otherwise have to travel farther. The school's governing body claimed that additional learners would exceed its capacity, and the provincial department retorted that the school was underusing its capacity as a ploy to exclude the fifty-five learners, owing to racial prejudice.

Apartheid racial classifications still shape South African identity politics and state-sponsored programmes to redress historic inequities. Within Apartheid classifications, the fifty-five learners are racialised as black, which provoked allegations of racism against Overvaal's predominantly white governing body. This already febrile situation was aggravated by Overvaal's language policy.

To clarify, South Africa officially endorses eleven languages, but only two enjoy widespread use in educational institutions: English and Afrikaans. Afrikaans remains closely associated with Apartheid and white dominance. Its presence in education, and the cultural capital sometimes conferred by proficiency in mainstream varieties of Afrikaans, has attracted accusations that its official usage sustains Apartheid-inspired divisions and inequalities by opening economic opportunities to those historically privileged by Apartheid. Overvaal High School provides education in Afrikaans, but since the fifty-five learners needed English instruction, the school's governing body asserted that its current infrastructure was unprepared. During January 2018, Member of the Executive Council (MEC) for Education in Gauteng, Panyaza Lesufi, entered the debate, levelling public allegations of racism against the school.

Ultimately, the case was tried in the Pretoria High Court, which upheld the school's original defence in terms of capacity and the inability to offer English instruction in time for the 2018 school year. Family members of the fifty-five learners responded by blocking the school gates during several days of protest action. Altercations erupted between protestors and other members of the community, including the family members of white children already enrolled at the school, until police forces intervened.

While the case is clearly contextualised by national currents and related histories, questions around access to education, racialisation and politicised blame games, speak to transnational concerns, and the research participates in these debates.

\section{RESEARCH AIMS}

Opinion columns represent a ubiquitous component of online news. As agenda-setting tools, they furnish sites for the exercise and contestation of social power. When opinion pieces hinge on blame games, readers are exposed to arguments and counter-arguments about the severity of the damage incurred by a newsworthy event and the potential guilt of human actors whose actions or inactions render them vulnerable to accusations (Nijjar 2015; Hansson 2018b). The language policies of South African institutions are instrumental to national programmes to redress Apartheid-based injustices and moves to cement English as the most expedient solution continues to stimulate debate in numerous spaces, including online news (Reygan and Steyn 2017). Overvaal, as an episode that occasioned violent confrontations across racial fault lines, constitutes an insightful case for discursively analysing knowledge construc- 
tion, racialisation and blame-attribution, as it emerges in the modes of reasoning that inflected media reactions.

This study aims to disclose patterns in these modes of reasoning by engaging with opinion pieces collected through purposively sampling. Three aims guided the analysis. First, the social actors who drew attention as potential candidates for blame were identified. Second, the study elucidates the warrants that structured inculpatory and exculpatory arguments for each candidate. Since warrants operate as "rules of inference [...] tied more strongly to concepts than to words", the analytic procedures used to extrapolate warrants from the opinion pieces can also uncover the assumptions that animate constructions of racism, and the calculated use of these constructions to rationalise blame-attribution (Grue 2009: 309). Third, based on the warrants that rationalised links between claims and evidence, the study interrogates the extent to which the opinion pieces treated Overvaal as interpolated with widespread contemporary racial inequity in South Africa. The basic terms of Toulmin's (2003) model are summarised in Table 1 below and detailed under a later heading.

Table 1: Toulmin's (2003) components of argumentation

\begin{tabular}{|l|l|}
\hline Claims: & $\begin{array}{l}\text { Statements or conclusions that remain contestable and require corroboration/justifi- } \\
\text { cation }\end{array}$ \\
\hline Data: & $\begin{array}{l}\text { Evidence or reasons provided to substantiate a claim. The nature of acceptable data } \\
\text { is defined and negotiated within the contextual parameters of the discourse setting. }\end{array}$ \\
\hline Warrants: & $\begin{array}{l}\text { Discursive elements that bridge data and claims, creating the logical infrastructure on } \\
\text { which an argument is premised. Warrants are typically rooted in presumably shared } \\
\text { views and values between addressers and addressees. }\end{array}$ \\
\hline
\end{tabular}

Source: own elaboration

The next part adumbrates race trouble, before explicating how it relates to discourse analysis of argumentation and blame games.

\section{RACE TROUBLE AS RELATED TO BLAME GAMES}

South Africa remains a fractured society, faced with recalcitrant disparities in access to social resources. Education represents a dramatic case in point. Over fifty percent of all adolescents who enter schooling leave before completing their senior stage. The majority of these are racialised as black, mainly from rural, low-income families (Reygan and Steyn 2017). The link between this dilemma and the reverberations of Apartheid is broadly accepted. However, debates rage over the extent to which other factors should attract blame, including government mismanagement, widespread corruption and global economic instabilities. By developing the concept race trouble, Cresswell et al. (2014) advance a method of probing interactional disagreements on these complexities, anchored in conversation analytic and discursive psychological techniques. 
At its core, race trouble uncovers the discursive construction of racism via interactional practices that render ideas about racism malleable and expedient to competing, situated interests. Such applications of race trouble drive research into contravening framings of racism. As one example of divisions around how racism should be theorised in South Africa, a deepening appreciation of racism as systemic has provoked calls for reconfiguring education, often voiced as the decolonial imperative, which aims to decentre Euro-centric pedagogies in favour of alternatives that address colonial and post-colonial conditions. Similar exhortations have been made to decolonise research by prioritising analytic models that address the repercussions of colonialism, neo-colonialism and neo-liberalism (Heleta 2016). On the other hand, anxieties abound that Apartheid history can be abused to obscure state corruption or to justify populist mobilisations driven by ethnic group identities. Divisive political figures such as Andile Mngxitama, Julius Malema and Floyd Shivambu have become key repositories of these anxieties.

Online news media constitute a cardinal site for the application of race trouble. Its multiple platforms facilitate regular and pronounced debates over the exact nature and severity of racism, and its impact on education (Reygan and Steyn 2017; Bosch 2017). The Overvaal episode represents an instance where such disagreements surfaced in online opinion pieces.

Race trouble supplies a means of cataloguing and interpreting discursive practices that are imbricated in these processes of meaning-making, "through which the continuing salience of race [is] reproduced in everyday interactions", including attempts to justify or denounce accusations of racism (Cresswell et al. 2014: 2514). Gaining analytic purchase on how racism is selectively constructed to affirm or refute its severity offers insight into its calculated appropriation to advance parochial interests (Cresswell et al. 2017). Adopting this approach does not deny material aspects of racial injustice. Instead, interactional mechanisms, once uncovered, are investigated to chart how participants link or omit other elements of racialised identities and positions.

For discourse analyse of blame games, the relevance of race trouble rests on the observation that making accusations of racism, or defending against them, requires implicit or explicit assumptions about racism. Arguments to condemn or defend those who stand accused of racism can nest their persuasive appeals in overtly-expressed or tacit claims about how society should measure racism. This implicit dimension of the discursive struggles that produce constructions of racism points to the utility of linking analyses of race trouble with Toulmin's (2003) theorisation of warrants (unpacked at a later stage), especially for the way warrants operate in race-relevance blame games.

Methodologically, relying on a case study to explore combinations between Toulmin (2003) and race trouble affords the advantage of scrutinising a naturally-occurring instance where race-relevant blame games are at stake. Before detailing the analytic procedures of Toulmin's (2003) framework, the next section clarifies my approach to opinion pieces. 


\section{ARGUMENTATION AND OPINION PIECES FROM A DISCOURSE ANALYTIC PERSPECTIVE}

Blame games are essentially interactive phenomena, and mapping how they might shape socio-political relationships demands cognisance of, "the fundamentally argumentative nature of politics" (Zienkowsky 2019: 135). Adegbola and Gearhart's (2019) comparative analyses of news consumption in the United States, Kenya and Nigeria, as well as Bosch (2017) and Buire and Staeheli's (2017) labours in South Africa, attest to the influence that mediatised arguments in online news can exercise on public perceptions of and reactions to divisive events. Hansson (2018a, b) illustrates how Toulmin's (2003) model can parse the discursive practices that set the terms an argument. Both accusatory and defensive arguments can invoke an innovative suite of cognitive, as well as affective appeals that assemble and normalise standards for judging culpability (Hansson 2018b; Boukala 2016; Nijjar 2015; Zagar 2010; Grue 2009).

Online spaces, including news sites, afford particularly powerful opportunities for contriving and contesting the normative grounds on which blame is settled, given the wide geographic and cross-demographic reach of internet-based texts. As such, online news sites were selected for this study to reflect their relatively stronger reach. Focusing on news sites that are available to internet users across South Africa is also especially valuable because events surrounding Overvaal attracted national attention, instead remaining a predominantly localised issue. Moreover, online news sources were also selected because adolescents are particularly prone to relying on online sources for news, as well as using knowledge peers as gatekeepers. That is to say, many adolescents access news via social media channels including Twitter and Facebook, by relying on the likes, recommendations, posts and reposts of peers who are recognised as thought leaders (Adegbola and Gearhart 2019; Mihailidis 2014). Such peer-led networks are increasingly influential in galvanising youth activists. Specifically, exposure to news (including opinions) via online peer gatekeepers has been linked with youth activists' efforts to grapple with emerging conceptualisations of civic engagement and democracy, as they attempt to destabilise exclusionary power dynamics premised on race, gender, sexual orientation and class. Movements such as Black Lives Matter, \#MeToo, \#FeesMustFall, \#RhodesMustFall, Open Stellenbosch and similar forms of activism attest to the collective, mobilising potential of networked movements in which various forms of argumentation (including news texts) circulate. The recurrence of the words fall and occupy in difference contexts could be read as gesturing towards the centrality of blame, and the transnational character of the concerns mobilising these protests has already been highlighted (Strong 2018). Media reactions to Overvaal contribute to this environment, since the event elicited significant media interest, including reactions from youth activists and recognised thought leaders, who interact in peer networks (Adegbola and Gearhart 2019; Strong 2018; Bosch 2017; Buire and Staeheli 2017; Hoffman and Mitchell 2016).

Of course, media texts such as opinion pieces and news reports never exercise a simplistic influence on audiences, even when opinions and reports are recommended by respected peers. The very networks that extend the reach of news media, also fur- 
nish opportunities for various readers to interrogate, reinterpret and even reject the content of the messages (Nijjar 2015; Mihailidis 2014). Nevertheless, the discursive practices that frame pressing political questions in opinion pieces still deserve critical inquiry, particularly in terms of the normative assumptions embedded in arguments, as authors labour to persuade their target readers. Such assumptions include notions regarding the conditions under which people, organisations and institutions should, or should not, be held liable the problems that instigate blame games (Nijjar 2015).

Opinion pieces, as opposed to news reports, take an overtly persuasive and argumentative stance. A discourse-driven interest in these persuasive goals entails sensitivity to the discursive repertoires on which they depend, as well as the concurrently constitutive and constituted character of these repertoires. Following Hansson (2018a) and Nijjar (2015), my approach pays particular attention to the persuasive and argumentative dimensions of opinion pieces, bearing in mind that they play a role in shaping the normative touchstones within which audiences are prompted to react to newsworthy events.

As is the case in many parts of the world where internet penetration is growing apace, online spaces facilitate interactions where divergent views on identity and equity can be adduced, nuanced, and supported or countermanded. As South Africans turn to online venues, where they share in the process of collective meaning-making, issues around racism emerge regularly and ignite hostility. Accusations and counter-accusations are traded while online interlocutors vie over the criteria by which behaviours, utterances, policies (including language policies), institutional cultures and other facets of socio-political life should be castigated as guilty of upholding racial injustice (Hansson 2018b; Bosch 2017).

As mentioned earlier, perennial disagreement over the legitimacy of accusations of racism suggests the appropriateness of merging race trouble with Toulmin (2003) as a means of understanding developments in South African online media. During the data collection and analysis, this interest propelled my choice to narrow the scope of this study to warrants, and their relationship with blame and race trouble. As expounded later, warrants bolster coherence between claims and evidence as to where blame should be apportioned in response to polarising events. Crucially, the process of examining warrants within blame games around Overvaal can be linked with efforts to map the trajectories of wider developments in South African online media, where questions around racialised subjectivity, equity and social cohesion often arise. Despite this focus on the parameters of a South African context, the findings of this study can nevertheless prove productive for comparative analyses in other contexts.

The complete list of opinion pieces on Overvaal, sampled for this study, is included in Table 2.

Toulmin's (2003) model, as well as Hansson's (2018a) subsequent work, supplies one route into these dynamics, as elucidated in the next section. 
Table 2: Warrants in opinion pieces on the Overvaal High School incident

\begin{tabular}{|c|c|c|c|c|}
\hline Topos & Description & $\begin{array}{l}\text { Title, author and } \\
\text { source of opinion } \\
\text { pieces that employ } \\
\text { this topos }\end{array}$ & $\begin{array}{l}\text { Primary tar- } \\
\text { gets of blame }\end{array}$ & Extract \\
\hline Diversity & $\begin{array}{l}\text { If schools } \\
\text { desire a di- } \\
\text { versity of } \\
\text { viewpoints, } \\
\text { they should } \\
\text { promote a } \\
\text { diverse body } \\
\text { of learners. }\end{array}$ & $\begin{array}{l}\text { How can our schools } \\
\text { ensure a more diverse } \\
\text { and non-racial soci- } \\
\text { ety? (Panyaza Lesufi, } \\
\text { Eyewitness News) }\end{array}$ & $\begin{array}{l}\text { SGBs of Afri- } \\
\text { kaans medi- } \\
\text { um schools }\end{array}$ & $\begin{array}{l}\text { The advocates of language } \\
\text { policies believe that admit- } \\
\text { ting other language groups } \\
\text { creates a diversity of view- } \\
\text { points in schools, the major } \\
\text { reason why racial division } \\
\text { remains entrenched in our } \\
\text { society. }\end{array}$ \\
\hline Utility & $\begin{array}{l}\text { If education } \\
\text { in English } \\
\text { secures ac- } \\
\text { cess to social } \\
\text { resources, } \\
\text { state-funded } \\
\text { schools must } \\
\text { each in En- } \\
\text { glish }\end{array}$ & $\begin{array}{l}\text { Every child will even- } \\
\text { tually need English } \\
\text { (Molula Musa, } \\
\text { News24) }\end{array}$ & $\begin{array}{l}\text { SGBs of Afri- } \\
\text { kaans medi- } \\
\text { um schools }\end{array}$ & $\begin{array}{l}\text { State-funded schools can- } \\
\text { not by any means argue to } \\
\text { teach in only one language } \\
\text { that is not English. Con- } \\
\text { sidering the fact that those } \\
\text { learners are supposed to go } \\
\text { to universities where the } \\
\text { medium of instruction is } \\
\text { English, I would like to be- } \\
\text { lieve that's not fair. }\end{array}$ \\
\hline $\begin{array}{l}\text { Autonomous } \\
\text { integration }\end{array}$ & $\begin{array}{l}\text { If schools are } \\
\text { permitted to } \\
\text { pursue racial } \\
\text { integration } \\
\text { autono- } \\
\text { mously, inte- } \\
\text { gration will } \\
\text { be successful }\end{array}$ & $\begin{array}{l}\text { Double medium } \\
\text { schools ideal for ra- } \\
\text { cial integration (Mot- } \\
\text { sumi Ntsebo, News24) }\end{array}$ & $\begin{array}{l}\text { The ANC-led } \\
\text { government }\end{array}$ & $\begin{array}{l}\text { If you look at double me- } \\
\text { dium schools in Sasolburg, } \\
\text { you find racially integrated } \\
\text { schools that give quality } \\
\text { education. Racial inte- } \\
\text { gration, however, was not } \\
\text { forced upon these schools. } \\
\text { It is something they chose } \\
\text { to do and it happened over } \\
\text { the years }\end{array}$ \\
\hline $\begin{array}{l}\text { Government } \\
\text { obligation }\end{array}$ & $\begin{array}{l}\text { If govern- } \\
\text { ment can } \\
\text { anticipate } \\
\text { problems in } \\
\text { educational } \\
\text { infrastruc- } \\
\text { ture, it is } \\
\text { obliged to } \\
\text { implement } \\
\text { precautions }\end{array}$ & $\begin{array}{l}\text { Language should not } \\
\text { be the dominant fac- } \\
\text { tor (Molefe Lengana, } \\
\text { News24) } \\
\\
\text { EFF is protesting at } \\
\text { the wrong place (Ani- } \\
\text { ta Ferri, News24) }\end{array}$ & $\begin{array}{l}\text { The EFF and } \\
\text { ANC-led gov- } \\
\text { ernment }\end{array}$ & $\begin{array}{l}\text { My take is that the ANC has } \\
\text { failed all South Africans in } \\
\text { nation-building and edu- } \\
\text { cation. I'm a firm believer } \\
\text { that a government governs } \\
\text { for all. } \\
\\
\text { The „esteemed” ruling } \\
\text { party must have known at } \\
\text { least } 7 \text { years ago how many } \\
\text { children they would have } \\
\text { had to accommodate but } \\
\text { unfortunately with the ANC } \\
\text { there isn't a problem until } \\
\text { there is a problem! No fore- } \\
\text { sight, no planning. They } \\
\text { are NOT proactive, they are } \\
\text { reactive. }\end{array}$ \\
\hline
\end{tabular}




\begin{tabular}{|c|c|c|c|c|}
\hline Law/protocol & $\begin{array}{l}\text { If a govern- } \\
\text { ment official } \\
\text { disregards } \\
\text { policies/laws, } \\
\text { that official } \\
\text { is guilty of } \\
\text { omission }\end{array}$ & $\begin{array}{l}\text { Was the Hoërskool } \\
\text { Overvaal crisis a plot } \\
\text { by Gauteng's edu- } \\
\text { cation department? } \\
\text { (Anthony Still, Busi- } \\
\text { ness LIVE) } \\
\\
\text { Hoërskool Overvaal: } \\
\text { Lesufi's awful record } \\
\text { (Sara Gon, Poli- } \\
\text { ticsweb) } \\
\text { Lesufi ignored the } \\
\text { constitution in Hoër- } \\
\text { skool Overvaal sage } \\
\text { (Katharine Child, } \\
\text { Timeslive) } \\
\text { Upgrade infrastruc- } \\
\text { ture and hire passion- } \\
\text { ate teachers (Craig } \\
\text { Joseph, News24) } \\
\text { Education problems: } \\
\text { Are Afrikaans schools } \\
\text { to blame? (Paul } \\
\text { Colditz, News24) } \\
\text { Overvaal: Where is } \\
\text { the moral leadership } \\
\text { (Melanie Verwoerd, } \\
\text { News24) }\end{array}$ & $\begin{array}{l}\text { MEC Panyaza } \\
\text { Lesufi } \\
\\
\text { MEC Panyaza } \\
\text { Lesufi } \\
\text { MEC Panyaza } \\
\text { Lesufi } \\
\\
\text { MEC Panyaza } \\
\text { Lesufi } \\
\\
\text { MEC Panyaza } \\
\text { Lesufi } \\
\text { MEC Panyaza } \\
\text { Lesufi }\end{array}$ & $\begin{array}{l}\text { See section on topos of law/ } \\
\text { protocol. }\end{array}$ \\
\hline $\begin{array}{l}\text { Human de- } \\
\text { velopment }\end{array}$ & $\begin{array}{l}\text { Since moth- } \\
\text { er tongues } \\
\text { are linked } \\
\text { to personal } \\
\text { identity, mul- } \\
\text { tilingual edu- } \\
\text { cation should } \\
\text { be provided }\end{array}$ & $\begin{array}{l}\text { Language: An emo- } \\
\text { tive issue (Bert Olivi- } \\
\text { er, Mail \& Guardian) }\end{array}$ & $\begin{array}{l}\text { The ANC-led } \\
\text { government }\end{array}$ & $\begin{array}{l}\text { Because one's 'own lan- } \\
\text { guage' - the one closest to } \\
\text { you - is inextricably and } \\
\text { intimately bound up with } \\
\text { your being human. [...] It is } \\
\text { therefore misguided on the } \\
\text { part of the ruling party, and } \\
\text { a great pity for indigenous } \\
\text { African language-speakers, } \\
\text { that it seems hell-bent on } \\
\text { creating an educational } \\
\text { environment of English } \\
\text { monolingualism, which is } \\
\text { linguistically and culturally } \\
\text { impoverishing for IsiZulu, } \\
\text { isiXhosa, and other indige- } \\
\text { nous mother tongue-speak- } \\
\text { ers in South Africa. }\end{array}$ \\
\hline
\end{tabular}




\begin{tabular}{|c|c|c|c|c|}
\hline $\begin{array}{l}\text { Cross-gener- } \\
\text { ational injus- } \\
\text { tice }\end{array}$ & $\begin{array}{l}\text { If systemic } \\
\text { injustice con- } \\
\text { tinues to af- } \\
\text { fect racialised } \\
\text { groups across } \\
\text { generations, } \\
\text { affected racial } \\
\text { groups merit } \\
\text { urgent re- } \\
\text { dress }\end{array}$ & $\begin{array}{l}\text { Hoërskool Overvaal: } \\
\text { blame SA's wealth } \\
\text { gap (Sydney Majoko, } \\
\text { The Citizen) } \\
\\
\text { Hoërskool Overvaal, } \\
\text { where language is a } \\
\text { proxy for race (Prince } \\
\text { Charles, Activate) }\end{array}$ & $\begin{array}{l}\text { } \\
\text { Apartheid-in- } \\
\text { spired eco- } \\
\text { nomic ar- } \\
\text { rangements }\end{array}$ & $\begin{array}{l}\text { Court rulings that en- } \\
\text { force the rights of Afri- } \\
\text { kaans-speaking pupils to } \\
\text { be protected at all costs } \\
\text { are legal. The side that } \\
\text { does not have the wealth } \\
\text { must turn to the courts to } \\
\text { force government to build } \\
\text { schools where they are } \\
\text { needed. But they are very } \\
\text { aware their disadvantaged } \\
\text { economic position is be- } \\
\text { ing used as a gatekeeping } \\
\text { mechanism to keep their } \\
\text { children from gaining ac- } \\
\text { cess to institutions } \\
\text { The situation at Hoerskool } \\
\text { Overvaal is a microcosm of } \\
\text { our nation and how it con- } \\
\text { tinues to approach issues } \\
\text { of transformation [...] as Ivo } \\
\text { Vegter eloquently articu- } \\
\text { lates it "we cannot replace } \\
\text { the dominant social order } \\
\text { of whiteness which caused } \\
\text { so much harm with black- } \\
\text { ness, which will cause just } \\
\text { as much harm". }\end{array}$ \\
\hline Co-operation & $\begin{array}{l}\text { If citizens } \\
\text { co-operate, } \\
\text { problems can } \\
\text { be solved }\end{array}$ & $\begin{array}{l}\text { Double shifts for } \\
\text { schools (Tobie Hen- } \\
\text { ning) } \\
\\
\text { Time to get our pri- } \\
\text { orities straight (Mat- } \\
\text { thew van Rensburg, } \\
\text { News24) }\end{array}$ & $\begin{array}{l}\text { MEC Panyaza } \\
\text { Lesufi } \\
\\
\text { All South Af- } \\
\text { rican political } \\
\text { parties }\end{array}$ & $\begin{array}{l}\text { We have a real problem in } \\
\text { South Africa. However, it } \\
\text { does not require racially } \\
\text { based arguments to get } \\
\text { to a solution Let's harness } \\
\text { the intellectual powers we } \\
\text { have and get the schools } \\
\text { to run with two shifts. [...] } \\
\text { Let's be positive and make } \\
\text { things work. } \\
\text { It's time to knuckle down } \\
\text { TOGETHER and start build- } \\
\text { ing for all those who don't } \\
\text { have and to kick to all the } \\
\text { self-serving politicians, } \\
\text { ANC, EFF, DA and every- } \\
\text { body in between out the } \\
\text { door as they only serve to } \\
\text { divide us. }\end{array}$ \\
\hline
\end{tabular}




\begin{tabular}{|l|l|l|l|l|}
\hline $\begin{array}{l}\text { Race-neutral } \\
\text { parents }\end{array}$ & $\begin{array}{l}\text { Because par- } \\
\text { ents want a } \\
\text { good educa- } \\
\text { tion for their } \\
\text { children, they } \\
\text { are not con- } \\
\text { cerned with } \\
\text { race }\end{array}$ & $\begin{array}{l}\text { A good teacher } \\
\text { knows no race } \\
\text { (Johann du Toit, } \\
\text { News24) }\end{array}$ & $\begin{array}{l}\text { Overvaal } \\
\text { teachers and } \\
\text { SGB }\end{array}$ & $\begin{array}{l}\text { All parents want a good ed- } \\
\text { ucation for their children. } \\
\text { Overvaal should feel priv- } \\
\text { ileged to be a school that } \\
\text { parents want their children } \\
\text { to attend. [...] In all my } \\
\text { years of teaching I never } \\
\text { had a parent complaining } \\
\text { about me being white. All } \\
\text { they wanted was a teacher } \\
\text { who is on time, well pre- } \\
\text { pared, knows the learners, } \\
\text { is a specialist in his/her } \\
\text { subject. }\end{array}$ \\
\hline
\end{tabular}

Source: own elaboration

\section{BLAME GAMES AND MORAL PANIC}

This section theorises blame as a social practice, and connects it with studies of moral panic, before explicating Toulmin's (2003) model of argumentation and its suitability to tracking blame-attribution.

Like many other nations, South Africa has witnessed escalations in online activism, offline protests with both violent and peaceful outcomes, as well as highly mediated tensions about the nature and implementation of social justice. Events from Occupy Nigeria to \#FeesMustFall, \#MeToo and \#WithoutUs, offer a gamut of opportunities for parsing constructions of blame and reflecting on what these permutations portend for the conceptualisation and pursuit of social justice (Buire and Staeheli 2017; Reygan and Steyn 2017; Bosch 2017). My attempts to track the manifestation of blame games under these conditions stems from three fundamental principles, derived from Tilly (2008; cf. Hansson 2018b; Leong and Howlett 2017; Boukala 2016; Nijjar 2015).

First, the socially mediated processes involved in conferring or withholding blame are often contested and protracted. The energy invested in confirming or denying blame is magnified by at least two factors: 1) the scope of the damage inflicted by an event such as exclusion from education, and 2) the intensity of disagreements over the most relevant standards for assessing the culpability of potential wrongdoers such as a school's governing body. In contrast with cases when acts of nature are blamed, human actors are more likely to face blame, if their actions/inactions can be linked with the harm incurred, which in turn demands criteria for making such judgements (Hansson 2018b; Leong and Howlett 2017; Boukala 2016; Nijjar 2015).

Second, as reactions to harm, these attempts to create and apply standards for adjudicating blameworthiness are contoured by the norms and expectations arising from existing social relationships. Simultaneously, the course of a blame game can decisively shift these relationships (Tilly 2008; Leong and Howlett 2017).

Third, mediatised blame games can become incorporated into narratives of moral panic (Nijjar 2015; Cohen 1972). The actions/inactions of those who are singled out for guilt can be constructed as grounds for moral outrage, especially under circumstance such as South Africa's history of racial oppression, which inject a moral dimen- 
sion into any race-relevant argument (Cresswell et al. 2014).

\section{CLAIMS AND WARRANTS IN BLAME GAMES}

Claims and warrants perform specific functions in the composition and rationalisation of blame games (Hansson 2018b).

To bolster the persuasiveness of an argument, accusatory claims assert and reassert that the event, which triggered the search for wrongdoers, was indeed negative enough to deserve public opprobrium. Defensive or blame-avoidant claims, by contrast, dispute the severity of whatever injury was suffered. If it has already been established that some hurt has been suffered, accusatory claims construct the causes of harm and adduce connections between those causes and the actions/inactions of potentially blameworthy social actors. Defensive claims attempt to uncouple the causes of damage from the actions/inactions of specific social actors.

In both cases, convincing audiences of the intentional involvement of possible blame-takers is instrumental, because actors are more likely to attract blame if they acted or failed to act of their own volition. Claiming that an actor inflicted harm unintentionally offers a possible escape from blame. Attesting or denying the intentional involvement of an actor pivots on two additional factors, both of which are susceptible to discursive construction and manipulation: obligations and capacity.

Obligations signify the duties associated with a given social role. In blame games, accusatory claims can indict an actor by asserting that he/she was officially obligated to predict and forestall problems, such as a shortage of space at public schools. Thus, even if such actors respond by claiming that they had not done harm intentionally, they can still be held liable, given their official obligation to honour the responsibilities incumbent upon their role.

Capacity speaks to an actor's wherewithal to execute the obligations associated with their role. Capacity is variously understood as including the necessary knowledge, information and resources required to exercise obligations. In blame games, accusatory claims verify that an actor was not only obligated to avoid harm, but also possessed the capacity to honour her/his duty. Defensive claims repudiate such allegations. For example, they might invoke wider, more powerful social forces such as economic constraints that prevented the person/institution from obeying their obligations. Essentially, defensive claims could argue that a target's agency/intentionally was suborned to external forces, which mitigate the target's blameworthiness (Hansson 2018b).

Foregrounding the obligations and capacities of some social actors, while omitting those associated with other potentially blameworthy actors, can strategically direct and deflect blame games. One outcome of such deflections is the production of oversimplified hero-villain narratives that obscure alternative narrations/framings (Hansson 2018a).

In addition to making claims, the authors of opinion pieces can chose to supply any type of evidence, as informed by predictions as to what might prove most persuasive to their target audiences.

Warrants specify the conditions under which evidence can be said to bolter claims. 
However, warrants are habitually communicated implicitly, given that audiences are often expected to "fill in the gaps" by relying on "assumed common ground" (Hansson 2018:232). As such, claims and evidence generally operate at a "surface” level, compared to the "deep" presence of warrants (Zagar 2010: 23). This characteristic of warrants makes them significant for scholarly attempts to unearth the underlying argumentative premises that structure and organise an argument's appeal to its audience. Of key significance for this study, analysing warrants also prompts consideration of alternative modes of reasoning that have been omitted from a blame game. This drives the consonant question as to whose concerns, values, norms, fears and anxieties are reflected in a discourse, and which alternatives are missing.

Finally, the implicit communication of warrants also suggests a connection with race trouble, since warrants may encompass assumptions about the nature of racism and, consequently, frame racism in ways that advance accusatory or defensive blame games.

Discourse analysts extrapolate warrants by first identifying the forms of evidence and claims that pervade an opinion piece, before inferring the tacit conditional links that are exigent for connecting evidence to claims (as illustrated in the findings; Hansson 2018b; Boukala 2016). For this reason, discourse analysts typically report warrants in if-A-then- $B$ conditional statements, such as the following: if accusations of racism are premised on self-serving political goals, then the targets of the accusation do not deserve blame. Crucially, the context-specific and ideologically-productive character of warrants implies that although they ostensibly rationalise claim-evidence structures, the warrants are also contingent and deserving of critique, as outlined during the findings.

\section{SAMPLING PROCEDURES}

A purposive sampling technique was applied over a three-month period, starting a few days after initial protests outside Overvaal High School. Collection was conducted through a Google search of all news items regarding Overvaal, before honing the search to pieces that were specifically marked as opinions, rather than comparatively non-argumentative reports. Collection continued until the end of April 2018. At this point, all opinion pieces related to Overvaal had already been sourced for the study and new texts were no longer being generated (as confirmed by additional searches in September 2018). Eventually, nineteen opinions had been gathered from numerous South African news portals. The complete list is summarised in Table 2.

Every opinion piece collected through this method was subjected to a qualitative discourse analysis, guided by the terms of Toulmin's (2003) model. This entails conducting a first-level reading during which broad patterns and these are ascertained. Next, the overall position advocated by each opinion piece was noted, followed by an attempt to meticulously identify the claims and supporting evidence strung throughout each text. These claim-evidence chains were then interrogated in order to extrapolate the warrants, or the conditional grounds on which evidence can be said to reinforce claims about where blame for controversy should be conferred. 
In deference to page constraints, the investigation reported below does not methodically interrogate factors related to the audiences' psychological readiness to read and unpack opinions that might question their existing values. Instead, I focus on mapping claims, evidence and warrants, as well as the construction of obligations, capacities, intentionality, and race trouble, as these factors emerge from the opinions piece. Additionally, page constraints also prevent a rigorous exposition of the background of each news outlet I visited when compiling the purposive sample for this study.

\section{RESEARCH RESULTS}

\section{LEGAL PROCEDURE AS GROUNDS FOR JUDGING BLAME}

Table 2 summarises all the warrants extrapolated from the sample. MEC Panzaya Lesufi was isolated as the central culprit across the opinion pieces, followed by the entire South African government (led by the African National Congress of which Lesufi is a member). While all the warrants reported in Table 2 deserve methodical exposition, this section concentrates on the primary blame target and the modes of reasoning that conferred liability upon the MEC.

Accusatory claims and supporting evidence against the MEC were discursively linked by a warrant that can be expressed as follows: If a government official disregards due legal procedure, that official is blameworthy. This warrant animates accusations against MEC Lesufi, premised on the claim that he has neglected legal procedures, specifically by making accusations against Overvaal's governing body before undertaking a methodical investigation into the details of the case. This warrant becomes entwined with a framing of racism as a political resource, inasmuch as Lesifu's allegations of racism against Overvaal are castigated as a move to advance his own reputation as an ardent anti-racist. Implicitly, this argument is adopted as grounds for exonerating Overvaal's governing body of racism. Consequently, the convergence between this warrant and this framing of racism circumvents a multi-layered understanding of racism, as detailed below.

In what follows, I account for my analysis by unpacking exemplars from several opinion pieces, in order to demonstrate the operation of this warrant, followed by a more textured analysis of the way it situates (or fails to situate) the Overvaal debacle within broader questions of structural racism in South African education. Doing so requires an elucidation of overlaps between the above-mentioned warrant and a context-specific enactment of race trouble.

As a shorthand, I refer to the above-mentioned warrant as a warrant of legal procedure. Six opinion pieces premised their attempts to blame the MEC on this warrant, and although the exact nature of the claims and evidence from these opinion pieces differ, all the arguments orbit the primary position that MEC Lesufi is guilty of exacerbating racial hostilities at Overvaal, instead of addressing and ameliorating racial injustice, as required by his office.

At is core, the blame games turn on an invocation of public officials' duty to identify 
forms of racial injustice and to mitigate these injustices, but to do so in compliance with constitutional stipulations, even at the cost of personal stakes. Numerous claims are proffered to insist that MEC Lesufi failed to honour these prescripts, coupled with evidence that were mainly sourced form: 1) his conduct during similar mediatised allegations of racism as well as 2) court rulings which should have guided his conduct around Overvaal. Citing court rulings as evidence becomes particularly functional for underscoring the MEC's capacity to discharge his obligations. To clarify, as MEC, Lesufi is expected to use earlier rulings as resources and therefore to address racism only after rigorous investigations that took cognisance of these rulings.

Positioning the MEC's charges of racism as a breach of conduct offers a method of undermining his credibility as an accuser in terms of both his obligations and capacity. To elaborate, MECs are not only expected to abide by legal procedures, but also to evince detailed knowledge of constitutional precedents from similar cases. In combination, therefore, the MEC is not simply charged with dereliction of duty, but also with ignoring sources of information, which should have directed his actions away from making public allegations of racism against Overvaal without first engaging with similar court cases. Consider the following exemplars from three separate opinion pieces:

Excerpt 1:

To some in the local media, Lesufi is a superstar - articulately and in dulcet tones slaying white, racist dragons in schools for violating the rights of their black victims. Except, this crusader often lights the racial fires or feeds the conflagration. [...] Overvaal is an Afrikaans-medium school. Its refusal to accommodate the 55 was because the school was already at capacity, with pupils who accepted Afrikaans as the medium of instruction, including black children. A single-medium school cannot become a dual-medium school overnight. The Act [Gauteng Schools' Education Act 6 of 1995] sets out grounds for admission: Section 18 (A) provides that the governing body must determine the language policy of the school subject to the Constitution.

\section{Excerpt 2:}

The Rivonia Constitutional Court judgment summarises three similar cases. Lesufi should therefore have known he had no chance of telling a school to take in 55 learners speaking a different language at the last minute in December, without fair procedure. But he went ahead anyway. In short, what Lesufi has done is pure politicking, turning an issue of insufficient places at quality schools into a spectacle.

\section{Excerpt 3:}

[Schools' governing bodies] are allowed to choose Afrikaans as their medium of instruction. They are also free to choose any other language, but in practice the only other language chosen is English. This is unlikely to change, despite what some ideologues might hope. Overvaal Hoërskool is full. This was confirmed by 
Judge Bill Prinsloo. [...] Gauteng MEC for Education Panyaza Lesufi ignored the Constitution when he turned the Hoërskool Overvaal wrangle into a racial drama with inflammatory statements like 'there is no racist that can hide behind a broomstick'.

These opinion pieces hold Lesufi liable for exacerbating racial aggression in direct contravention of his obligation to promote equity and social justice. The claims hinge on the view that dereliction of legal procedure turns Lesufi into a transgressor. However, accusing the MEC of neglect is also developed into grounds for positioning his actions as guilty of intentional politicking. Agency is according to Lesufi, premised on the view that access to earlier court rulings underscores his capacity to obey the obligation to adhere to formally recognised investigative procedures. A platform is thus built, on which to hold him liable for seeking to bolster his own reputation as an advocate of racial justice.

Hansson (2018a), Boukala (2016) and Grue (2009) aver that the persuasive efficacy of a warrant emanates from its resonance with an audience's epistemic assumptions. Of course, the author of an opinion pieces could misjudge the existing worldviews and normative frameworks within which the audience operates. However, if the author possesses adequate insight into the audience, and if the argument resonates with the audience, then appealing to implicitly-held assumptions can invite members of the audience to interpret the argument as legitimising these assumptions. Additionally, the author can become positioned as a promoter and defender of the audience's values, if linkages between an argument's underlying premises and an audience's values have been made.

Within this perspective, the analysis advanced thus far suggests that a warrant of legal procedure might resonate with expectations that public officials must follow constitutional prescripts to the letter. However, inasmuch as the blame games also involve racism, another discursive practice is also present, one that can be brought under critical scrutiny through the lens of race trouble. The warrant of legal procedure becomes entangled with anxiety over the way politicians abuse allegations of racism for parochial gain. Audiences are clearly expected to harbour some knowledge of the risk that the racial hostilities sparked by mediatised events can be fuelled and exploited in a politician's bid to jockey for advantage, such as the value of being publically lauded as an anti-racist. Scrutinising blame-attribution from the perspective of race trouble therefore permits inquiry into these dimensions of blame-relevant argumentation.

Put differently, these opinion pieces situate the MEC not simply as an individual wrongdoer. Instead, his behaviour is symptomatic of a wider danger that accusations of racism might buttress the power and narrow interests of political elites, at the expense of other social actors (specifically culturally white education institutions, in this case).

The argumentative practices that ascribe intentionality to the MEC are vital in this regard. Lesufi is not simply accused of neglecting legal procedure by omitting penetrating investigation of the details at Overvaal, or of failing in his duty to consult 
prior court rulings. He is charged with actively ignoring relevant information with the aim of victimising Overvaal and, by implication, to entrench his growing status as, "a superstar - articulately and in dulcet tones slaying white, racist dragons” (Excerpt 1). The crusader metaphor proffered in Excerpt 1 poignantly demonstrates this anxiety. Not only is Lesufi staged as a putative, but ultimately underserving, hero; white South Africans and Afrikaans institutions who attract his attention are framed as innocents who have been undeservingly framed as monsters. By flipping the hero-monster, or victim-villain narrative, until Lesufi becomes the perpetrator and Afrikaans institutions become the victims, the blame games resist more finely-contoured analyses, which could have exposed audiences to multi-perspectival viewpoints.

Of salient interest to scholars of racialisation and race trouble, the anxiety underpinning this warrant and its role in the blame games under study, is readable as a form of moral panic. The panic is closely allied to the omission of other aspects of racism besides its potential for exploitation by self-interested politicians. Before elucidating this element of the analysis, however, it should be noted that some of the opinion pieces did acknowledge systemic, historically-anchored facets of racial inequities. The following section deals with these acknowledgments and their function, before transitioning to moral panic.

\section{ACKNOWLEDGING SYSTEMIC RACISM}

While the above-mentioned trend to inculpate MEC Lesufi prevailed in the pieces sampled for this study, several texts injected a level of ambiguity into the analysis by making arguments that are comparatively more complex. In particular, these opinions gestured towards a more contextually nuanced reading of Overvaaal, by reading it as symptomatic of broader issues. Nevertheless, many of the limitations outlined in the previous section were not significantly decentred, as elucidated below.

Five opinion pieces historicised the inscription of racialised hierarchies on access to education in South Africa. However, three of these pieces failed to substantively incorporate the acknowledgement into the trajectory of their arguments. Instead, the blame games articulated in these three pieces resume efforts to blame the MEC. As a result, allusions to Apartheid are not taken as a junction at which to consider the possibility that, regardless of the MEC's potential self-interest, systemic disparities are nevertheless to blame for the lack of space in South African schools. Consider the following three examples:

Excerpt 4:

"Apartheid has left us with many scars. The worst of these must be the vast discrepancy in access to public and private resources. [...] Unequal access to opportunity prevailed in every domain. Access to private or public education was no exception". [...] It [the Rivonia Constitutional Court] went on to say: "It is how we manage those competing interests and the spectrum of views that is pivotal to developing a way forward". The Constitution provides us with a reference point - the best interests of our children. The trouble begins when we lose sight 
of that reference point, when we become more absorbed in staking out the power to have the final say, rather than in fostering partnerships to meet the educational needs of children. As tensions simmer outside Hoërskool Overvaal, it is hard to conclude that Lesufi has taken the best interests of the children into account.

\section{Excerpt 5:}

Functional schools are making every effort to reach out to disadvantaged communities and schools in the midst of their own overcrowded programs. This includes Afrikaans schools. However, there is little that any individual school can do to cope with or solve the massive systemic problems.

\section{Excerpt 6:}

Let me also emphasise that I am totally infuriated by the fact that so many children, particularly African children, still have no access to a proper education. I am ashamed at the role my ancestors played in this legacy.

By invoking history, the opinion pieces encounter an opportunity to expand the scope of its examination to cover other types of racism, which might be at play at Overvaal, especially by recognising the contemporary impact of Apartheid. These invocations take both explicit and implicit forms. For example, the outwardly neutral and purportedly non-historical reference to "functional schools" in Extract 5 is readable as racialised, since the descriptors functional and quality are often assigned to historically white-only schools (Reygan and Steyn 2017). However, instead of offering a more capacious scope, which could deepen the critical weight of their discussions, the authors who make these references swiftly return their attention to exonerating Overvaal in terms of the school's capacity (see Excerpt 5), or back to renewed assertions of Lesufi's individual guilt (see Excerpt 4). Similarly, Excerpt 6 begins to historicise Overvaal by contextualising poor access to quality education as an outcome of earlier racist hierarchies. The author also self-racialises as white by mentioning, "the role my ancestors played in this legacy”. However, since the effort to contextualise Overvaal ends here, the manoeuvre becomes readable as an instance of what Leonardo and Zembylas (2013: 150-151) have termed, "a non-racist alibi”, which conveniently locates racism as someone or something out here, "residing elsewhere in other whites". The potential benefit of this self-presentational strategy, in which the author labours to project an anti-racist persona, suggests that linking Overvaal to Apartheid becomes a form of interest convergence (Aguirre 2010). That is, an admission that racism is both historically-rooted as well as a present reality at the level of social structures, is adopted when other benefits, such as presenting the self as unbiased and committed to social justice, can be achieved. As a result, the primacy of a constructing racism as a politically exploitable resource remains mainly uncontested and compliant with the form of moral panic discussed under the next section (it should be noted that other authors did not openly self-racialise after the fashion of Extract 6).

Only two opinion pieces acknowledged the ramifications of Apartheid while con- 
currently according prominence to this recognition. These two pieces did not exclusively frame racism as an exploitable resource, opting instead to also construct current racialised injustices as an outgrowth of Apartheid arrangements:

Excerpt 7:

A casual observer can easily be fooled into believing that because the court ruling focused on the capacity of the school, it is merely a game of numbers. It runs deeper than that. At its most basic, the parents of the 55 pupils, who are mostly black and demanding to be taught in English, are bearing the brunt of government's failure to build successful English/ African language schools in areas that are predominantly Afrikaans, but have a significant number of black people living there. The reason Mandela is always invoked by the young ones as a sellout is because while reconciliation continues to be preached as the underlying principle of our constitution [the] wealthy are very quick to run to the courts to ensure that there is no encroachment on their privileged lifestyles.

\section{Excerpt 8:}

The situation at Hoerskool Overvaal is a mircrocosm of our nation and how it continues to approach issues of transformation, what is certain however is if we continue to use language as proxy for race violence is a guaranteed outcome, violence is contrary to the spirit of our constitution.

The opinion pieces from which these extracts were sourced avoid treating the Overvaal furore as an isolated case in which an unfortunate shortage of space forced the exclusion of black learners, or a straightforward instance in which a politician like Lesufi seized upon a racially fraught situation to strengthen his reputation. Instead, the event is contextualised in terms of broader inequalities and read as "a microcosm" that indexes the limitations of the negotiated settlement that ended Apartheid, but left many of its unequal structures intact (see Excerpt 8). They read the event and the violent protests that followed as an exhortation to engage with the racialised distribution of wealth.

\section{DISCUSSION: RACE TROUBLE, BLAME-ATTRIBUTION AND MORAL PANIC}

There is no necessary connection between the construction of racism as a political resource and the assumption that sidestepping legal procedures invalidates accusations of racism. Instead, the connection represents an argumentative contrivance of the texts under study. Formulating the two as intimately connected cumulatively produces a type of moral panic. This panic produces a false binary: either the governing body at Overvaal is guilty of racism, or the MEC is guilty of politicking. Alternatives remain either entirely overlooked, or at least underexplored. For example, the governing body at Overvaal might harbour prejudice regardless of the MEC's self-interested political manoeuvres, and, more importantly, regardless of either of these factors, other elements of racism deserve exploration in news media, as elaborated in this section. 
To start, the warrant of legal procedure is enacted in a manner that concomitantly racialises and de-racialises the blame games. Insufficient space at schools is mainly glossed over as a race-neutral problem. Adolescents racialised as black face tremendous impediments to education, especially those from rural areas who are often compelled to travel significant distances to enter education (Reygan and Steyn 2017). Nevertheless, the opinion pieces rarely centred these factors in their development of blame games.

However, as affirmed by the earlier analysis from the perspective of race trouble, MEC Lesufi's public allegations of racism against the governing body of Overvaal High School are racialised. His premature charges are configured as grounds for public outcry and as indexing a moral failing in the leadership of the Gauteng Department of Education. His racialised identity as a black politician in a country encumbered by high rates of government corruption, ineptitude and malpractice, render him vulnerable to such narratives of moral panic.

To clarify, narratives that charge government officials with abusing the power of their office are ubiquitous in South African media. To varying degrees, government corruption has indeed curbed economic growth as well as post-1994 restitution projects, including the expansion of educational infrastructures in areas historically neglected by the state apparatuses of Apartheid. Anxieties over government corruption are real and deserve urgent attention. Moreover, they are not unique to South Africa. Therefore, given these very real concerns over government accountability, politicians' real commitment to social justice, and the danger of populist mobilisations in South Africa, my analysis is not intended to militate against journalistic enterprises to keep government officials accountable. Of course, journalists and other contributors to mediatised blame games should scrutinise politicians and all social elites, and expose how they might exploit problems such as racism. However, precisely because of the democratic imperative to monitor all social elites and to hold them accountable for the advancement of social justice, scholars should investigate instances when the imperative to counter corruption and malpractice become imbricated in dangerous simplifications, which are peddled to serve narrower interests and panics. I suggest that in this case study, most of the opinion pieces stymie opportunities for strident engagement with deeper elements of racism.

On that basis, the findings caution against the way Afrikaans institutions are configured as besieged by the partisan manoeuvres of politicians like MEC Lesufi. The former are positioned as merely defending the rights constitutionally accorded to Afrikaans as an official language, while the latter's transgressions and malpractices are folded into a victim-villain narrative that ultimately overshadows and excises other equally relevant axes of socio-political analysis.

\section{CONCLUSION}

Online communication channels afford opportunities for cultivating the critical faculties of audiences. The forms knowledge (and ideologies) proliferated through online media retain a capacity to calibrate how audiences engage with dominant construc- 
tions of identity, the operation of power, and the subtle or explicit manifestation of exclusion. Opinion pieces, news reports and comment section are cardinal constituents of this online environment, and can play a role in augmenting or enervating critical thinking by exposing readers to simplified or comparatively more richly-nuanced narratives. Even discourses complicit in instigating and inflecting moral panics can become multi-vocal and facilitate robust interaction between countervailing viewpoints, "due to a proliferation of media platforms and the diversity of opinions that operate within them” (Nijjar 2015: 2).

Relying on Toulmin (2003), Hansson (2018a) and race trouble (Cresswell et al. 2014) prompted this investigation into the way constructions of racism become folded into the argumentative warrants that tacitly rationalise blame-attribution in the opinion pieces. The results denote the function of a specific warrant in organising the blame games around a type of moral panic, premised on recycling an existing anxiety that social elites can mobilise allegations of racism to further partisan and parochial interests instead of expanding social justice.

It should be noted that a warrant of legal procedure is not inherently problematic or automatically susceptible to the power-evasive practices outlined in the analysis. Potentially, this warrant can be wed to an unpredictable array of argumentative positions. All warrants and their roles in blame games remain contingent and contestable, since they remain both constituted by, and constitutive of wider social relations and processes. In the opinion pieces under study, however, this warrant and the claim that events at Overvaal are entirely innocent of racism are drawn into a process of convergence, which occurs, "when two or more activities are linked in the process of signification” (Hall, Critcher, Jefferson, Clarke and Roberts 1978). For this reason, the implications of selectively converging this warrant with a single (and problematically truncated) understanding of racism deserve criticism for its simplified victim-villain narrative.

FUNDING: This research received no external funding.

CONFLICT OF INTEREST: The author declares no conflict of interest.

\section{REFERENCES}

Adegbola, Oluseyi and Sherice Gearhart. 2019. “Examining the relationship between media use and political engagement: A comparative study among the United States, Kenya, and Nigeria.” International Journal of Communication 13: 12311251.

Aguirre, Adalberto. 2010. "Diversity as interest-convergence in academia: A critical race theory story." Social Identities 16(6): 763-774.

Bosch, Tanya. 2017. "Twitter activism and youth in South Africa: The case of \#RhodesMustFall.” Information, Communication and Society 20(2): 221-232.

Boukala, Salomi. 2016. "Rethinking topos in the discourse historical approach: Endoxon seeking and argumentation in Greek media discourses on 'Islamist terror- 
ism'.” Discourse Studies 18(3): 249-268.

Buire, Chloe and Lynn Staeheli. 2017. "Contesting the 'active' in active citizenship: Youth activism in Cape Town, South Africa." Space and Polity 21(2): 173-190.

Cohen, Stanely. 1972. Folk Devils and Moral Panics: The Creation of the Mods and Rockers. Oxford: Basil Blackwell Ltd.

Cresswell, Catherine, Kevin Whitehead, and Kevin Durrheim. 2014. "The anatomy of 'race trouble' in online interactions." Ethnic and Racial Studies 37(14): 2512-2528.

Grue, Jan. 2009. "Critical discourse analysis, topoi and mystification: Disability policy documents from a Norwegian NGO.” Discourse Studies 11(3): 305-328.

Hall, Stuart, Charles Critcher, Tony Jefferson, John Clarke, and Brian Roberts. 1978. Policing the Crisis: Mugging, the State, and Law and Order. Basingstroke: Macmillan Publishers Ltd.

Hansson, Sten. 2018a. "The discursive micro-politics of blame-avoidance: Unpacking the language of government blame games." Policy Sciences 51: 545-564.

Hansson, Sten. 2018b. "Analysing opposition-government blame games: Argument models and strategic manoeuvring." Critical Discourse Studies 15(3): 228-246.

Heleta, Savo. 2016. "Decolonisation of higher education: Dismantling epistemic violence and Eurocentrism in South Africa." Transformation in Higher Education 1(1): 1-8.

Hoffman, Garrett and Tania Mitchell. 2016. "Making diversity "everyone's business": A discourse analysis of institutional responses to student activism for equity and inclusion." Journal of Diversity in Higher Education 9(3): 277-289.

Leonardo, Zeus and Michalinos Zembylas. 2013. "Whiteness as a technology of affect: Implications for educational praxis." Equity and Excellence in Education 46(1): 150-165.

Leong, Ching and Michael Howlett. 2017. "On credit and blame: Disentangling the motivations of public policy decision-making behaviour." Policy Sciences 50: 599-618.

Mihailidis, Paul. 2014. "The civic-social media disconnect: Exploring perceptions of social media for engagement in the daily life of college students." Information, Communication \& Society 17(9): 1059-1071.

Nijjar, Jasbinder. 2015. "Menacing youth and broken families: A critical discourse analysis of the reporting of the 2011 English Riots in the Daily Express using moral panic theory." Sociological Research Online 20(4): 1-12.

Reygan, Finn and Melissa Steyn. 2017. "Diversity in basic education in South Africa: Intersectionality and Critical Diversity Literacy.” African Education Review 14(2): 68-81.

Strong, Krystal. 2018. "Do African lives matter to Black Lives Matter? Youth uprisings and the borders of solidarity." Urban Education 53(2): 265-285.

Tilly, Charles. 2008. Credit and Blame. Princeton: Princeton University Press.

Toulmin, Stephen. 2003. The Uses of Argument. Cambridge: Cambridge University Press.

Zagar, Igor. 2010. “Topoi in critical discourse analysis.” Lodz Papers in Pragmatics 6(1): 3-27. 
Zienkowsky, Jan. 2019. "Politics and the political in critical discourse studies: The state of the art and a call for an intensified focus on the metapolitical dimension of discursive practice." Critical Discourse Studies 16(2): 131-148.

\section{BIOGRAPHICAL NOTE}

Marthinus Stander Conradie holds a $\mathrm{PhD}$ in critical discourse analysis and inferential pragmatics from the University of the Free State (South Africa), where he is currently employed at the Department of English. His research interests are grounded in discourse analysis and critical race theory, which he has applied to examine everyday political argumentation, the construction of race and racism as well as whiteness. His publications include analyses of South African students' online discussions of personal experiences of racial discrimination and micro-aggressions on university campuses, citizens' online deliberations via asynchronous news forums, as well as media depictions of Africa in print advertising.

OPEN ACCESS: This article is distributed under the terms of the Creative Commons Attribution Non-commercial License (CC BY-NC 4.0) which permits any non-commercial use, and reproduction in any medium, provided the original author(s) and source are credited.

ARTICLE HISTORY: Received 2019-09-30 / Accepted 2020-02-22 